\title{
The Effect of Investment, Exports, and Interest Rates on the Gross Domestic Product of the Republic Of Yemen: An Econometric Analysis
}

\author{
Prof. Mohammed Y. AL-Rafik ${ }^{1}$ \\ ${ }^{1}$ Former President of Thamar University, Faculty Member, Department of Financial and Banking \\ Sciences, Faculty of Administrative Sciences, Thamar University, Yemen
}

\begin{tabular}{|c|c|}
\hline Article Info & Abstract \\
\hline $\begin{array}{l}\text { Article History: } \\
\text { Received: 05 May } 2021\end{array}$ & $\begin{array}{l}\text { Purpose: The study aims to examine the effect of investment, exports, and } \\
\text { interest rates on the gross domestic product of the Republic of Yemen. }\end{array}$ \\
\hline Revised: 16 August 2021 & Approach/Methodology/Design: This study is based on secondary data. Data \\
\hline Accepted: 22 August 2021 & $\begin{array}{l}\text { on the gross domestic product, interest rate, gross capital formation were } \\
\text { obtained and analyzed using the autoregressive distributed lag (ARDL) }\end{array}$ \\
\hline & $\begin{array}{l}\text { technique, Wald test, Serial Correlation LM Test. The data were presented the } \\
\text { Findings: The results through the use of the (E-VIEWS) program showed that }\end{array}$ \\
\hline $\begin{array}{l}\text { Investment, Interest Rate, } \\
\text { Export, Gross Domestic }\end{array}$ & $\begin{array}{l}\text { there is a direct statistically significant relationship at a level of } 5 \% \text { between } \\
\text { investment and gross domestic product. This means that if investment }\end{array}$ \\
\hline Product & $\begin{array}{l}\text { increases by } 1 \% \text {, it will lead to an increase in GDP by } 28.63 \% \text {. The result } \\
\text { also showed that the dummy variable relationship to the GDP is direct and }\end{array}$ \\
\hline JEL: L1, G31, G32 & $\begin{array}{l}\text { statistically significant. The level of significance is } 5 \% \text {, that is, by increasing } \\
\text { the dummy variable by } 1 \% \text {, it leads to an increase in GDP by } 25.13 \% \text {. As long }\end{array}$ \\
\hline Paper Type : & as the interest rate was on an inverse relationship and statistically significant \\
\hline Research Article & $\begin{array}{l}\text { at a significant level (10\%), this means that an increase in interest rates by } \\
1 \% \text { would lead to a decrease in GDP rates by } 19.54 \% \text {. In addition, there is a }\end{array}$ \\
\hline Corresponding Author: & $\begin{array}{l}\text { positive relationship between exports and GDP and a statistical significance } \\
\text { at level } 5 \% \text {. This means that an increase in exports by } 1 \% \text { leads to an increase } \\
\text { in GDP by } 6976 \% \text {. }\end{array}$ \\
\hline $\begin{array}{l}\text { Prof. Mohammed Y. AL- } \\
\text { Rafik }\end{array}$ & $\begin{array}{l}\text { Practical Implications: The investment could be double more than what the } \\
\text { results showed in the case of political and economic stability. Improving }\end{array}$ \\
\hline $\begin{array}{l}\text { Email: } \\
\text { dalrafikmy@tu.edu.ye }\end{array}$ & $\begin{array}{l}\text { legislation is also a significant aspect. There is an urgent need to focus on } \\
\text { investment in infrastructure. In addition, increasing exports improve the gross } \\
\text { domestic product. Based on the results, it is recommended to real invest } \\
\text { instead of placing capital in banks as increasing interest rates lead to lower } \\
\text { gross domestic output. } \\
\text { Originality/value: The analysis indicates that there is a direct statistical and } \\
\text { significant relationship between total investment and gross domestic product } \\
\text { at a significant level of 5\%, as whenever the investment increased by } 1 \% \text {, this } \\
\text { led to an increase in the gross domestic product by about } 28.63 \% \text {. }\end{array}$ \\
\hline
\end{tabular}

\section{Introduction}

Investing in many ways is of great importance to the economy in any country. Real investment, financial investment, and investment in the manner of build-operate-transfer (BOT) in developing the infrastructure of the state and society are the main pillars of economy. The urbanization of countries and the extent of their progress are measured by their interest in investment in all sectors and infrastructure development. It is considered the backbone and the main factor on which major investments and projects depend, contributing to the development of society and providing a healthy and safe environment for the individual and society. Investment in the national capital in the manner of building, operating, and transferring (BOT) is also one of the most important investments that play a major role in the economic development, 
especially when focusing on developing the infrastructure, as many economists emphasize its importance. In addition, investment in infrastructure is a major factor in attracting capital for investments in other sectors.

Economists have measured the return from infrastructure development and it is found out that it contributes in one way or another to economic growth. Infrastructure is vital to economic development, as it is key to achieving higher and stable economic growth. (Ismail \& Mahyideen, 2015). Infrastructure, for example, plays a key role in facilitating trade. Studies have confirmed that infrastructure development helps the growth of other sectors and, therefore, the interest in investing in infrastructure is considered as a leading sector in facilitating investments. Infrastructure is a key element of poverty alleviation. It often acts as a catalyst to development and enhances the impact of interventions to improve the poor's access to other assets (Gaal \& Afrah 2017). In other sectors, there is a direct contribution to increasing the national income, by raising the efficiency of services, whether direct or indirect.

From this point of view, this study aims to identify the impact of investment on the gross domestic product given the turbulent situation in the country. Investment in Yemen currently faces many challenges and obstacles, whether political, economic, or social. Therefore, it is necessary to focus on policies and procedures that improve the current situation and attract capital. Capital is a coward; looking for safety to achieve the maximum possible earnings. Hence, efforts must be doubled to ensure the safety of national capital and provide the necessary facilities for all investors.

Given the importance of investment in creating developments in all fields under normal circumstances, and due to the war in the country, it is necessary to study the impact of investment on the gross domestic product. Yemen is a country with a wide spectrum of economic potential for several industries and shows a bright and promising future for its agriculture and fishery sectors (Badeeb \& Lean, 2017). However, there are many obstacles to investment, whether political, economic, structural, or legislative. For instance, Yahya et al. (2017) indicated that political instability in Yemen has a positive and significant influence on bank's profitability. It is well-established that capital is cowardly and always looking for a safe zone to invest in and achieve maximum profit. Accordingly, the study is significant and will have practical implications for concerned authorities. Given the unstable conditions in Yemen, the study provides a venue for investment operations during a turbulent period in Yemen. Four hypotheses are formulated as follows:

1. There is no direct statistically significant relationship between total investment and gross domestic product.

2. There is no direct statistically significant relationship between export and gross domestic product.

3. There is no direct statistically significant relationship between interest rates and gross domestic product.

4. There is no direct relationship between the dummy variable (expressing events) and GDP. 


\section{Methodology and Procedures}

The study employs the descriptive methodology and the standard analytical methodology. This study is based on secondary data. Data on the gross domestic product, interest rate, gross capital formation were obtained and analyzed using the autoregressive distributed lag (ARDL) technique, Wald test, Serial Correlation LM Test. GDP in terms of a record was presented by using the E-VIEWS program.

\section{Results and Discussion}

\section{The impact of investment and some variables on the gross domestic product:}

\section{Defining the model variables and studying their stability:}

Many variables affect the Gross Domestic Product (GDP), and accordingly, this study will place some variables that affect the GDP, the most important of which are total investment (I), interest rates $(\mathrm{R})$ and exports $(\mathrm{X})$, and the dummy variable will be added. (Phantom), which expresses the occurrence of important events during the study and is symbolized by the symbol (D)

\section{The model for multiple linear regression would be as follows:}

\section{Defining the variables:}

$\mathrm{GDPt}=\mathrm{F}(\mathrm{I}, \mathrm{X}, \mathrm{R}, \mathrm{Dummy})$

whereas:

I: It represents the total investment. GDP: Gross domestic product at current prices.

$\mathrm{R}$ : Represents the rate of interest rates. $\quad \mathrm{X}$ : Exports. $\quad \alpha 0$ : constant amount.

$\alpha 1, \alpha 2, \alpha 3$ : Coefficients of independent variables.

Annual time series data for the variables included in the model, in addition to the rest of the indicators that may affect the gross domestic product for the period (2000-2015), were collected from the annual statistical reports issued by the Central Bureau of Statistics and the Central Bank of Yemen and Appendix No. (1) clarifies these raw data. The data were divided into quarterly data using custom formulas, and this was based on previous studies, such as Al-Rafik's study (2009) and Al-Bazai's study (1999). The quarterly data are shown in Appendix No. (2).

\section{Studying the stability of variables:}

To study the stability of the variables that are used in the model, the variables are tested because the time series of many macroeconomic indicators are unstable. Therefore, it is preferable to test the variables first for the unit root, and the model includes the regression estimation of an unstable series. The time series is stable if both the mean and the variance are constant across time. At the same time, the subjective difference coefficient depends on the gap between those two periods, and not on the actual time in which the differential coefficient is prominent. On the other hand, the time series needs the difference for stability.

Usually, Phillips-Person or the Dickey-Fuller test are employed. This test includes an estimate of the equation formulated as follows (Stock, 2003; Fuller, 1996; Said \& Dickey. 1984; Said, 1991):

Copyright (C) 2020, Journal of Advanced Research in Economics and Administrative Sciences (JAREAS), Under a 


$$
\Delta G D P_{t}=a+b_{1} G D P_{t-1}+u_{t}
$$

The Extended Dickey-Fuller (ADF) test takes the following form:

$$
\Delta G D P_{t}=a+b_{1} G D P_{t-1}+\sum b_{i} G D P_{t-i}+u_{t}
$$

Where: $\Delta$ denotes the first differences, a: denotes the second.

It appears from Table No. (1) after conducting a study of the stability of the variables included in the model through the outputs of the E-VIWES program, using Phillips-Person, that the variables are stable at the first difference, whether in the case of the constant or in the case of the temporal trend or the absence of the constant and temporal direction.

\begin{tabular}{|c|c|c|c|c|c|c|}
\hline in the level & \multicolumn{6}{|c|}{ UNIT ROOT TEST TABLE (PP) } \\
\hline Variables & DUMMY & $\mathbf{R}$ & $\mathbf{X}$ & I & GDP & \\
\hline \multirow[b]{2}{*}{ With difficulty } & -0.6088 & -1.9693 & -1.6534 & -1.4390 & -1.3082 & t-Statistic \\
\hline & 0.8599 & 0.2992 & 0.4490 & 0.5566 & 0.6196 & P- Value \\
\hline \multirow{2}{*}{$\begin{array}{l}\text { With constant and temporal } \\
\text { direction }\end{array}$} & -1.9338 & -2.2314 & 0.2494 & -1.2315 & -0.2279 & t-Statistic \\
\hline & 0.6234 & 0.4632 & 0.9979 & 0.8938 & 0.9908 & P-Value \\
\hline \multirow{2}{*}{$\begin{array}{l}\text { Without static and without } \\
\text { temporal direction }\end{array}$} & 0.0000 & -0.2091 & 0.1796 & 0.7005 & 1.9615 & t-Statistic \\
\hline & 0.6784 & 0.6064 & 0.7345 & 0.8638 & 0.9872 & P- Value \\
\hline \multicolumn{7}{|l|}{ When the first difference } \\
\hline \multirow[t]{2}{*}{ With difficulty } & -7.3485 & -4.4279 & -2.9938 & -4.6308 & -3.4346 & t-Statistic \\
\hline & 0.0000 & 0.0008 & 0.0418 & 0.0004 & 0.0139 & P- Value \\
\hline \multirow{2}{*}{$\begin{array}{l}\text { With constant and temporal } \\
\text { direction }\end{array}$} & -7.3556 & -4.3918 & -3.2842 & -4.6943 & -3.8186 & t-Statistic \\
\hline & 0.0000 & 0.0049 & 0.0798 & 0.0020 & 0.0230 & P-Value \\
\hline \multirow{2}{*}{$\begin{array}{l}\text { Without static and without } \\
\text { temporal direction }\end{array}$} & -7.2801 & -4.4629 & -3.0484 & -4.5120 & -2.8978 & t-Statistic \\
\hline & 0.0000 & 0.0000 & 0.0029 & 0.0000 & 0.0045 & P-Value \\
\hline
\end{tabular}

Table No.1: Time Series Variables (Phillips-Person) Test Results

Source: Prepared by the researcher based on the data in Appendix No. (2) of the E-Views program outputs

\section{Building the Auto Regressive Distributed Lags (ARDL):}

This method is considered one of the advanced methods of processing models based on studying and analyzing time-series data. Through the ARDL model, we can determine the complementary relationship between the dependent variable and the independent variables, in addition to determining the size of the effect of all independent variables on the dependent variable in the short and long terms.

The advantage of the ARDL model is that it can combine variables with more than one level of stability, such as I (0) and I (1), and it is not required that all of them be stable at the same level, as it depends on the SBC standard (Schwarz Bayesian Criteria) that is used to determine the number of slowdowns Optimum and gives an error correction result that measures the ability of the model to balance after an emergency malfunction or disturbance.

$$
\begin{aligned}
& \Delta\left(G D P_{t}\right)=c+\lambda\left(G D P_{t-1}\right)+\alpha_{1}\left(I_{t-1}\right)+\alpha_{2}\left(X_{t-1}\right)+\alpha_{3}\left(R_{t-1}\right)+\alpha_{4}\left(\text { Dummy }_{t-1}\right)+\sum_{i=1}^{m} \beta_{1, i} * \Delta\left(G D P_{t-i}\right)+ \\
& \sum_{i=1}^{k} \beta_{2, i} * \Delta\left(I_{t-1}\right)+\sum_{i=1}^{k} \beta_{3, i} * \Delta\left(X_{t-1}\right)+\sum_{i=1}^{k} \beta_{4, i} * \Delta\left(R_{t-1}\right)+\sum_{i=1}^{k} \beta_{5, i} * \Delta\left(D u m m y_{t-1}\right)+u_{t}
\end{aligned}
$$


whereas :

GDP: domestic product. I: Total investment. R: Interest rates. X: Exports. .

Dummy: The dummy. Ut: random error

The equation (4) consists of three parts, which are as follows:

Part One: $\quad c+\lambda\left(G D P_{t-1}\right)+\alpha_{1}\left(I_{t-1}\right)+\alpha_{2}\left(X_{t-1}\right)+\alpha_{3}\left(R_{t-1}\right)+\alpha_{4}\left(\right.$ Dummy $\left._{t-1}\right)$

From it, we obtain the long-term information or the long-term relationship and the series of the five variables at the level represent slower for one year. Through the information we obtain from this part, we get the joint integration equation (equation of the long-term relationship between GDP and the independent variables) and according to the ARDL method,

The parameters of the independent variables $(1 \alpha, 2 \alpha, 3 \alpha, 4 \alpha)$ do not have an economic meaning, but a statistical meaning, and can be used to obtain the marginal tendency or elasticity (if using the logarithm of time series) for the independent variables (I, R, X, Dummy) In the long-term relationship model if we have the following regression equation:

$$
\begin{aligned}
& \mathrm{GDP}_{\mathrm{t}}=\beta+\mathrm{b}_{1}(\mathrm{I})+\mathrm{b}_{2}(\mathrm{X})+\mathrm{b}_{3}(\mathrm{R})+\mathrm{b}_{4}(\text { Dummy })+\mathrm{U}_{\mathrm{t}} \\
& \beta=\frac{-c}{\lambda}, b_{1}=\frac{-\alpha_{1}}{\lambda}, b_{2}=\frac{-\alpha_{2}}{\lambda}, b_{3}=\frac{-\alpha_{3}}{\lambda}, b_{4}=\frac{-\alpha_{4}}{\lambda}
\end{aligned}
$$

The parameter is required to be negative to have a long-term relationship and the possibility of returning to equilibrium. It represents the percentage of the short-term error that can be corrected per unit of time and which represents a fraction of the year in this model.

Part Two: is represented by the slowdowns of the dependent variable.

$\sum_{i=1}^{m} \beta_{1, i} * \Delta\left(G D P_{t-i}\right)$

- The third part: is represented by the slowdowns of the independent variables.

$$
\sum_{i=1}^{k} \beta_{2, i} * \Delta\left(I_{t-1}\right)+\sum_{i=1}^{k} \beta_{3, i} * \Delta\left(X_{t-1}\right)+\sum_{i=1}^{k} \beta_{4, i} * \Delta\left(R_{t-1}\right)+\sum_{i=1}^{k} \beta_{5, i} * \Delta\left(\text { Dummy }_{t-1}\right)
$$

As the second and third parts of the equation represent short-term information.

\section{Estimated Model Tests and Results Analysis:}

The model is estimated using the (OLS) method within the programming of the (ARDL) model, and after this step of estimating using the E-VIEWS program, we obtain the results shown in Appendix No. (4) and are organized in the following table: 
Table No. 2: Choosing the best results of slowdowns out of the total

\begin{tabular}{|c|c|c|c|c|c|}
\hline Statement & GDP & I & $\mathbf{X}$ & $\mathbf{R}$ & Dummy \\
\hline $\begin{array}{l}\text { Number of models evaluated } \\
\text { slowdowns }\end{array}$ & 2500 & & & & \\
\hline $\begin{array}{l}\text { Best number of slowdowns } \\
\text { selected }\end{array}$ & 1 & 4 & 4 & 2 & 4 \\
\hline Views & 52 & & & & \\
\hline
\end{tabular}

Source: Prepared by the researcher depending on the data in Appendix No. (2) using the ARDL form

Table No. (3) shows that the number of evaluated slowdown models that were completed through the E-VIEWS program amounted to 2,500 models and that the ARDL model is distinguished by choosing the best slowdown periods for each variable according to Appendix No. (4), where it worked on choosing one slowest period for the output variable. The selection of 4 slower periods for the total investment variable, 2 slower periods for the interest rate variable, 4 slower periods for the export variable, and 4 slower periods for the dummy variable, where the selection was made based on the results of Akike Info Criterion (AIC) selection, and we note from the appendix the number of views was 52 views for each variable.

\section{Test for long-term error correction potential and conditions for the error correction parameter signal and significance $\mathrm{s:}$}

Table No. 3: Significant test results and signal correction factor

\begin{tabular}{|c|c|c|c|c|}
\hline $\begin{array}{l}\text { Parameter correction } \\
\text { The error }\end{array}$ & Parameter value & Standard error & T-test & P-Value \\
\hline$\lambda$ & -0.268782 & 0.019565 & -13.738011 & 0.0000 \\
\hline Independent variables & Parameter value & Standard error & T-test & P-Value \\
\hline Total investment (I Ln) & 0.286312 & 0.079287 & 3.611062 & 0.0010 \\
\hline Exports (X Ln) & 0.697582 & 0.131185 & 5.317528 & 0.0000 \\
\hline Interest rate $(\mathrm{R} \mathrm{Ln})$ & -0.195372 & 0.111341 & -1.754722 & 0.0889 \\
\hline Dummy variable & 0.251320 & 0.047359 & 5.306693 & 0.0000 \\
\hline Static Limit (C) & -2.873099 & 1.582788 & -1.815215 & 0.0789 \\
\hline \multicolumn{5}{|c|}{$\begin{array}{l}\operatorname{Ln}\left(G^{\prime} P_{t}\right)=\beta+b_{1}(\operatorname{Ln~I})+b_{2}(\operatorname{LnX})+b_{3}(\operatorname{Ln~R})+b_{4}(\text { Dummy })+U_{t} \\
\operatorname{Ln}\left(G P_{t}\right)=-2.873099+0.286312(\operatorname{Ln~I})+0.697582(\operatorname{LnX})-0.195372(\operatorname{LnR})+0.251320(\text { Dummy }) \quad(10)\end{array}$} \\
\hline
\end{tabular}

Source: Prepared by the researcher depending on the data in Appendix No. (2) using the ARDL form

It appears from the results in Table (3) that the analysis will take two directions:

- The first analysis is represented by a negative value (-0.268782), which is significant, as the value of t-test $=-13.738011$ and the value of $\mathrm{P}$ - Value $=0.000$, which is less than $1 \%$, and this means fulfilling the conditions of the error correction parameter that was mentioned previously. Thus, there is the possibility of correcting the short-term error in the long term and returning to the equilibrium position, that is; 13.74 percent of the shortterm error is addressed in the long term.

- The second analysis: It is represented by the value of the t-test for each of the total investments, exports, and the dummy variable, which was about (3.61, 5.32, and 5.31), respectively, and it is statistically significant because the P-value was less than $5 \%$. The total investment, exports, and the dummy variable are by $1 \%$. This will lead to an increase in the GDP by $(28.63 \%, 69.76 \%$, and $25.13 \%)$ respectively. Although the dummy variable expresses the occurrence of events in the period (2011-2015) and is 
assumed to be the sign of the coefficient of the dummy variable, it is negative. Its effect on the gross domestic product is negative, but it appears that the effect of the dummy variable was positive. This is due to several reasons, including the existence of instability, money laundering, investments increased in many projects. such as exchange companies, and oil stations. There may be some capital owners who could not get their money out. They, therefore, invested it in real estate, private hospitals, private schools, and private universities. Therefore, all the transactions of the independent variables express the elasticities of output with respect to total investment, exports, and other variables. The effect of each variable is positive, while the variable related to interest rates was at the value of t-test $=-0.195372$, which is statistically significant at $10 \%$ and P-value $=$ 0.0889. Therefore, an increase in the interest rate of $1 \%$ will lead to a decrease in the gross domestic product by $19.54 \%$, which expresses the flexibility of the product with the interest rate. All the independent variables are consistent with the economic theory.

\section{WALD TEST to examine the existence of a long-term relationship:}

After establishing an equation for the impact of investment and some variables on the gross domestic product during the long term, the signal correction factor test was accepted. Another important test is done to decide whether or not the model is accepted. It involves testing the existence of a long-term relationship, starting from the independent variables included in the model (I, X, R, Dummy) to the dependent variable (GDP). Therefore, the BONDS TEST within the E-VIEWS program is used, depending on the F distribution and is based on the following optional rule:

\section{The test hypotheses are:}

There is no long-term relationship that goes from the independent variables to the dependent variable: $\mathrm{H} 0$

There is a long-term relationship that goes from the independent variables to the dependent variable: $\mathrm{H} 1$

The comparison for this test is done through the tabular values developed by Pesaran, as there is an upper limit I1 and a minimum I0 dependent on the number of independent variables $\mathrm{K}$. If the value of $\mathrm{F}$ is greater than $\mathrm{I} 1$, we reject $\mathrm{H} 0$ and accept $\mathrm{H} 1$, meaning that there is a long-term relationship that moves from the independent variables to the dependent variable. If the value of $F$ is smaller than $\mathrm{I} 0$, we accept $\mathrm{H} 0$ and reject $\mathrm{H} 1$, meaning that there is no long-term relationship that moves from the independent variables to the dependent variable. But if F is between I1 and $\mathrm{I} 0$, then in this case the decision is not specified (that is, we cannot make the decision).

After applying the test through the E-VIEWS program, we obtain the results shown in Appendix No. (7) and arranged in Table No. (5), in which a long-term relationship appears, moving from the independent variables to the dependent variable, as well as judging the explanatory ability of the estimated model in the short term and hence the judgment of the quality of the estimated model as a whole. 
Table No. 5: Results of WALD TEST examining the existence of a long-term relationship

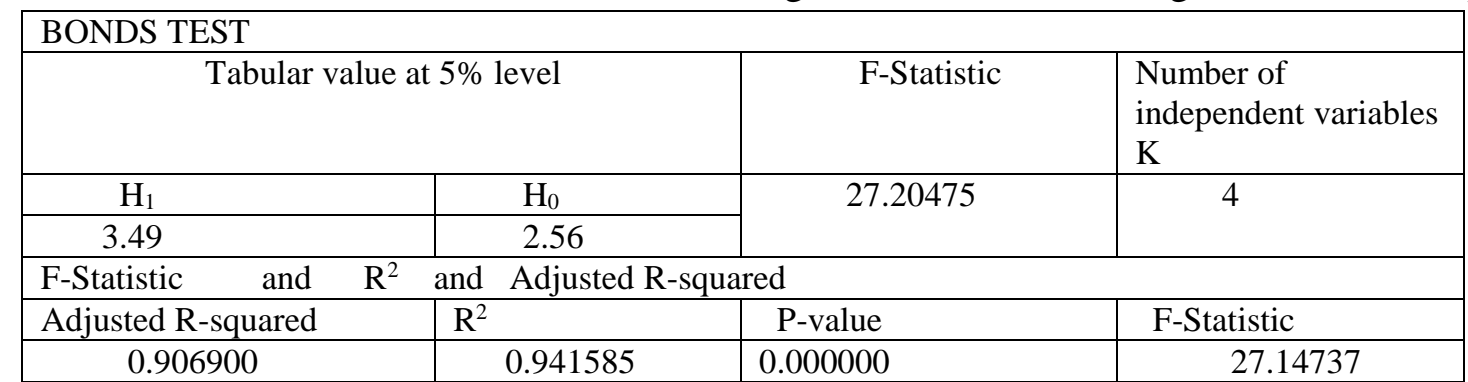

Source: Prepared by the researcher using the data in Appendix No. (2) using the ARDL form

It appears from the above table that the value of $F=27.20$, which is greater than the highest tabular value, i.e. higher than 3.49. This means the existence of a long-term relationship leads the independent variables to the dependent variable. Therefore, we reject hypothesis $\mathrm{H} 0$ and accept hypothesis $\mathrm{H} 1$, meaning that there is a long-term relationship that leads from the independent variables (I, X, R, and Dummy) to the dependent variable (GDP).

R2, which shows the explanatory ability of the estimated model over the long term, which we arrived at through equation (10), confirms to us that $94 \%$ of the change in GDP comes from independent variables, which is a high percentage that reflects the good choice of the model representing the relationship under study. Therefore, the value of the Adjusted R-squared coefficient, which takes into account the number of observations and the number of estimators, was supportive of the estimated model and the explanatory capacity, as it reached $91 \%$.

Given the value of $\mathrm{F}=27.15$ and the $\mathrm{P}$-value $=0.000$, we reject the null hypothesis and accept the alternative hypothesis which states that the estimated parameters differ from zero, meaning that the estimated regression equation for the impact of investment and some variables on GDP are statistically significant. This explains the investment effect on GDP, and the value of F, R2 and Adjusted R-squared reflects the overall significance of the model in the short term, which appears in Appendix No. (7).

\section{Serial Correlation LM Test:}

According to ARDL methodology, the discovery of the auto clinking problem is done through the Breusch-Godfrey test which is based on the idea of the Lagrange multiplier LM Test for series correlation. It cautions many economists against using the Durban-Watson (DW) test in this model. This test is based on the F-test statistic and Chi-Square statistic and is structured

The test is as follows:

- No self-correlation for H0 errors:

- There is a self-correlation for H1 errors:

Then the calculated values for each Chi-Square or F-statistic are compared or based on their probabilities that appear in the test, where the comparison is made as follows:

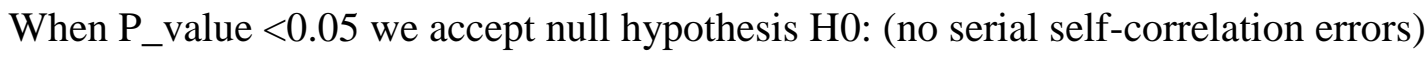

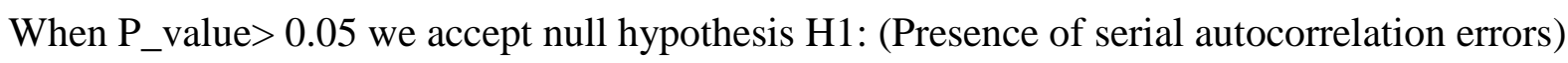


After applying the test through the E-VIEWS program, we obtain the results shown in Appendix No. (6), which were summarized in the following table:

From the previous Table (6), we note that the probability of the F and Chi statistics is significant. Its probabilities were greater than the level of 5\% and thus we accept the null hypothesis, which states that there is no self-sequential correlation of errors in the investment impact model and some variables on the estimated GDP, meaning that the variance of errors is homogeneous.

Table (6): Serial Correlation LM Test results

\begin{tabular}{|l|l|l|}
\hline P-Value & Test value & Statement \\
\hline 0.7411 & 0.302197 & F-statistic \\
\hline 0.6432 & 0.882712 & Chi-Square \\
\hline
\end{tabular}

Source: Prepared by the researcher depending on the data in Appendix No. (2) using the ARDL form

\section{Conclusion and Suggestion}

After studying the effect of investment, exports, and interest rates on the gross domestic product of the Republic of Yemen, the data revealed that Yemen is in dire need of investments in all sectors, especially in infrastructure. There are some obstacles to investment, the most important of which are economic, political, structural, and legislative. Based on the results of the study, the investment requirements lie in real investment and investment in infrastructure. The analysis indicates that there is a direct statistical and significant relationship between total investment and gross domestic product at a significant level of 5\%, as whenever the investment increased by $1 \%$, this leads to an increase in the gross domestic product by about $28.63 \%$. The results of the impact of exports on the GDP indicated that it has a positive relationship with the GDP at the level of significance of $5 \%$, meaning that whenever exports increase by $1 \%$, this leads to an increase in GDP by $69.76 \%$. The independent variable represented in interest rates had a negative effect on the GDP, which is statistically significant at the level of $10 \%$, that is; by increasing interest rates by $1 \%$, this leads to a decrease in the GDP by about $19.54 \%$. More importantly, the analysis showed that the dummy variable (which expresses the situation in Yemen) had a direct relationship and statistical significance at the level of 5\%.

Based on the results of the study, there is a need to pay attention to investments and to provide facilities for all investors, whether local or international. It is also imperative to assess the economic, political, structural, and legal obstacles and urgently work on overcoming them. Collaboration of efforts among all institutions and ministries is recommended to eliminate investment obstacles facing national and foreign capital. It is also important for authorities and concerned bodies to invest in all sectors, especially infrastructure. Encouraging real investments and reducing investments in financial derivatives may improve the gross domestic product.

\section{Conflict of Interests}

The author declares no conflict of interest.

\section{Funding}

For this research work, the author did not receive funds from any organization.

Copyright (C) 2020, Journal of Advanced Research in Economics and Administrative Sciences (JAREAS), Under a 


\section{References}

Abu Muammar, F. (2006). The Role of Banks in Investing in Palestine for the Period 1990-2000. The Journal of the Islamic University, 10, (1), 16-29.

Akter, A., Hossain, M. I., Reaz, M., Bagum, T., Tabash, M., \& Karim, A. M. (2020). Impact of demographics, social capital and participation in income generating activities (IGAs) on economic empowerment of rural women in Bangladesh. Test Engineering and Management, 1911-1924.

Al-Bazai, H. S. (1999). The Role of Money in Saudi Arabia: A Dynamic Analysis. Economics and Administration, 13(1).

Al-Idrisi, A. (1986). Macroeconomic Analysis, University of Basra Press.

Al-Dehi, S.(2004). Investment Restrictions, Financial Restrictions with Application to Yemen. Economic Studies, 11,28-41.

Al-Rafik, M.(2010). The Impact of Investment in Education on Economic Growth in the Republic of Yemen: An Analytical Standard Study. Shu'un Al-Asr Magazine.

Al-Mandi, M.(2009). Investment Climate in Yemen: Evaluation of Fifteen Years' Experience (1990-2005), Yemeni Economic Conference, Yemeni Center for Strategic Studies.

Ismail, W., \& Mahyideen, J. M. (2015). The Impact of infrastructure on trade and economic growth in selected economies in Asia. ADBI Working Paper Series

Ben Achi, B.(2011). The Role of Intellectual Capital in Achieving Total Quality in Industrial Institutions. (MBA Thesis), Mohamed Khedir University.

Badeeb, R. A., \& Lean, H. H. (2017). Financial development, oil dependence and economic growth: Evidence from the Republic of Yemen. Studies in Economics and Finance. 34(2), 281-298. http://dx.doi.org/10.1108/SEF-07-2014-0137

Gaal, H. O., \& Afrah, N. A. (2017). Lack of Infrastructure: The Impact on Economic Development as a case of Benadir region and Hir-shabelle, Somalia. Developing Country Studies, 7(1).49-55.

Fuller, W. A. (2009). Introduction to statistical time series (Vol. 428). John Wiley \& Sons.

Said, S. E., \& Dickey, D. A. (1984). Testing for unit roots in autoregressive-moving average models of unknown order. Biometrika, 71(3), 599-607.

Said, S. E. (1991). Unit-roots test for time-series data with a linear time trend. Journal of Econometrics, 47(2-3), 285-303.

Sen, L. K., \& Shitan, M. (2002). The performance of AICC as an order selection criterion in ARMA time series models. Pertanika Journal of Science and Technology, 10(1), 25-33.

Stock, J. H., \& W Watson, M. (2003). Introduction to Econometrics. Pearson Education, Inc.

The General Investment Authority, Republic of Yemen, published data on the most important investment indicators in the Republic of Yemen.

Yahya, A. T., Akhtar, A., \& Tabash, M. I. (2017). The impact of political instability, macroeconomic and bank-specific factors on the profitability of Islamic banks: an empirical evidence. Investment Management and Financial Innovations, 14(4), 30-39.

Copyright (C) 2020, Journal of Advanced Research in Economics and Administrative Sciences (JAREAS), Under a 
Appendices

\section{Appendix No. (1)}

Total investment, GDP, interest rate and exports in the Republic of Yemen for the period (2000 -2015)

\begin{tabular}{|l|c|l|c|c|c|}
\hline YEARS & $\begin{array}{l}\text { DUMMY } \\
\text { VAR }\end{array}$ & $\begin{array}{l}\text { Export By } \\
\text { thousand }\end{array}$ & Interest Rate \% & GDP In million riyals & $\begin{array}{c}\text { Total of Investment } \\
\text { In million riyals }\end{array}$ \\
\hline 2000 & 0 & $613,937,112$ & 13 & 1560926 & 266481 \\
\hline 2001 & 0 & $521,629,032$ & 13 & 1684554 & 286940 \\
\hline 2002 & 0 & $540,732,149$ & 13 & 1878007 & 297,754 \\
\hline 2003 & 0 & $659,476,436$ & 13 & 2160608 & 411,755 \\
\hline 2004 & 0 & $731,781,051$ & 13 & 2563490 & 493,537 \\
\hline 2005 & 0 & $1,040,657,905$ & 13 & 3208501 & 806,119 \\
\hline 2006 & 0 & $1,270,866,272$ & 13 & $4,265,586$ & $1,121,344$ \\
\hline 2007 & 0 & $1,214,516,246$ & 13 & $4,845,838$ & $1,378,156$ \\
\hline 2008 & 0 & $1,438,333,210$ & 13 & $5,711,289$ & $1,534,091$ \\
\hline 2009 & 0 & $1,225,847,862$ & 10 & $5,772,915$ & $1,239,261$ \\
\hline 2010 & 0 & $1,361,809,897$ & 20 & $6,786,814$ & $1,299,867$ \\
\hline 2011 & 1 & $1,482,141,374$ & 20 & $6,644,660$ & $1,168,212$ \\
\hline 2012 & 1 & $1,471,754,070$ & 18 & $6,875,253$ & $1,326,845$ \\
\hline 2013 & 1 & $1,539,178,595$ & 15 & $7,468,564$ & $1,145,868$ \\
\hline 2014 & 1 & $1,334,893,400$ & 15 & $7,139,534$ & $1,506,048$ \\
\hline 2015 & 1 & $168,227,913$ & 15 & $5,729,031$ & 600,636 \\
\hline
\end{tabular}

Source: 1) Ministry of Planning and International Cooperation, Statistical Yearbook, various issues.

2) The Central Bank of Yemen, the annual report prepared differently.

Appendix No. (2)

Total investment, GDP, interest rate and exports in the Republic of Yemen for the period Divided into a

\begin{tabular}{|c|c|c|c|c|c|}
\hline $\begin{array}{c}\text { the years } \\
\text { Divided } \\
\text { Quarter }\end{array}$ & DUMMY VAR & $\begin{array}{c}\text { Interest } \\
\text { rates } \\
\mathbf{R}\end{array}$ & $\begin{array}{c}\text { EXPORT } \\
\mathbf{X}\end{array}$ & $\begin{array}{c}\text { Total } \\
\text { Investment } \\
\text { I }\end{array}$ & GDP \\
\hline $2001: 1$ & 0 & 3.25 & 134881556.73 & 70288.39 & 407376.91 \\
\hline $2001: 2$ & 0 & 3.25 & 130680407.04 & 71321.74 & 415638.43 \\
\hline $2001: 3$ & 0 & 3.26 & 128879410.88 & 72566.99 & 427237.41 \\
\hline $2001: 4$ & 0 & 3.25 & 127846453.86 & 73125.55 & 436547.35 \\
\hline $2002: 1$ & 0 & 3.25 & 129678577.54 & 69492.46 & 448503.15 \\
\hline $2002: 2$ & 0 & 3.25 & 132250475.82 & 71681.86 & 461366.71 \\
\hline $2002: 3$ & 0 & 3.26 & 137151735.99 & 75952.91 & 478187.95 \\
\hline $2002: 4$ & 0 & 3.25 & 142423330.06 & 81095.61 & 492513.47 \\
\hline $2003: 1$ & 0 & 3.25 & 155768392.91 & 93645.51 & 509672.98 \\
\hline $2003: 2$ & 0 & 3.25 & 162246895.94 & 100131.43 & 528501.33 \\
\hline $2003: 3$ & 0 & 3.26 & 168875777.08 & 106693.83 & 552229.82 \\
\hline $2003: 4$ & 0 & 3.25 & 173461600.24 & 111864.29 & 573224.01 \\
\hline
\end{tabular}




\begin{tabular}{|c|c|c|c|c|c|}
\hline 2004:1 & 0 & 3.25 & 167167681.19 & 106865.01 & 594490.71 \\
\hline 2004:2 & 0 & 3.25 & 175140490.25 & 115418.61 & 622606.93 \\
\hline 2004:3 & 0 & 3.26 & 187989003.27 & 128467.99 & 658241.24 \\
\hline 2004:4 & 0 & 3.25 & 202661956.16 & 143673.76 & 691884.72 \\
\hline 2005:1 & 0 & 3.25 & 234623479.40 & 172387.97 & 726618.66 \\
\hline $2005: 2$ & 0 & 3.25 & 252356063.90 & 191699.61 & 772309.64 \\
\hline $2005: 3$ & 0 & 3.26 & 270346256.70 & 212327.79 & 829339.17 \\
\hline $2005: 4$ & 0 & 3.25 & 284819301.76 & 230978.86 & 885131.36 \\
\hline 2006:1 & 0 & 3.25 & 307746890.29 & 253435.31 & 987327.52 \\
\hline 2006:2 & 0 & 3.25 & 317239485.26 & 271854.42 & 1044539.56 \\
\hline 2006:3 & 0 & 3.26 & 323765623.04 & 290970.92 & 1100067.59 \\
\hline 2006:4 & 0 & 3.25 & 323626723.89 & 306693.74 & 1139420.22 \\
\hline 2007:1 & 0 & 3.25 & 298369344.17 & 324857.92 & 1147520.13 \\
\hline 2007:2 & 0 & 3.25 & 298822885.57 & 338878.18 & 1186641.56 \\
\hline $2007: 3$ & 0 & 3.26 & 305350727.27 & 353157.21 & 1236959.94 \\
\hline $2007: 4$ & 0 & 3.25 & 313668579.25 & 363098.16 & 1281455.66 \\
\hline 2008:1 & 0 & 3.37 & 356117080.39 & 387016.97 & 1379968.35 \\
\hline 2008:2 & 0 & 3.32 & 362815948.57 & 389215.71 & 1419618.56 \\
\hline 2008:3 & 0 & 3.24 & 364273324.64 & 385990.58 & 1453785.34 \\
\hline 2008:4 & 0 & 3.09 & 356704769.43 & 373489.32 & 1464997.09 \\
\hline 2009:1 & 0 & 2.28 & 313176641.89 & 323981.19 & 1402160.59 \\
\hline 2009:2 & 0 & 2.29 & 304934525.97 & 310697.27 & 1418981.66 \\
\hline 2009:3 & 0 & 2.53 & 303768801.34 & 304547.65 & 1458699.95 \\
\hline 2009:4 & 0 & 2.93 & 305598051.50 & 301613.73 & 1501086.00 \\
\hline 2010:1 & 0 & 4.46 & 328765960.33 & 327223.61 & 1649045.55 \\
\hline 2010:2 & 0 & 4.92 & 336570040.94 & 327579.41 & 1692117.04 \\
\hline 2010:3 & 0 & 5.25 & 345913140.42 & 326410.52 & 1725339.26 \\
\hline 2010:4 & 0 & 5.39 & 352344079.81 & 320133.81 & 1728531.99 \\
\hline 2011:1 & 1 & 5.08 & 364849249.77 & 293442.52 & 1662125.18 \\
\hline 2011:2 & 1 & 5.05 & 369839033.07 & 289362.87 & 1656870.12 \\
\hline
\end{tabular}




\begin{tabular}{|l|l|l|l|l|l|}
\hline $2011: 3$ & 1 & 5.00 & 374599367.14 & 291400.09 & 1665821.57 \\
\hline $2011: 4$ & 1 & 4.89 & 374667409.34 & 295586.19 & 1668223.60 \\
\hline $2012: 1$ & 1 & 4.73 & 366358676.05 & 330542.43 & 1685296.22 \\
\hline $2012: 2$ & 1 & 4.59 & 366439211.48 & 334714.43 & 1703105.11 \\
\hline $2012: 3$ & 1 & 4.44 & 369606885.37 & 335047.46 & 1735573.82 \\
\hline $2012: 4$ & 1 & 4.26 & 371220236.68 & 328009.82 & 1760268.39 \\
\hline $2013: 1$ & 1 & 3.92 & 389594510.13 & 282674.14 & 1850009.36 \\
\hline $2013: 2$ & 1 & 3.77 & 389056508.18 & 279437.81 & 1870219.70 \\
\hline $2013: 3$ & 1 & 3.69 & 385981016.30 & 286393.35 & 1884904.07 \\
\hline $2013: 4$ & 1 & 3.63 & 376255893.38 & 299096.28 & 1872321.08 \\
\hline $2014: 1$ & 1 & 3.75 & 390906176.06 & 392676.14 & 1860328.44 \\
\hline $2014: 2$ & 1 & 3.75 & 362665456.39 & 394921.85 & 1820515.41 \\
\hline $2014: 3$ & 1 & 3.76 & 319974652.70 & 378423.92 & 1771311.14 \\
\hline $2014: 4$ & 1 & 3.75 & 261939034.80 & 341063.65 & 1694891.18 \\
\hline
\end{tabular}

Source: The process of dividing the data into quarter was done based on the data in Appendix No. (1)

1- AL-Rafik, Muhammad Yahia, The Impact of Investment on Economic Growth in the Republic of Yemen, An Analytical Standard Study, Journal of Ashoun Al-Udar.

2- Hammed s. AL- BAZAI, "The Role of Money in Saudi Arabia," j.kau: Econ. \& Adm. (1999) VOL.13.No. 1, pp37.

1st quarter $=0.05469 \mathrm{X} \mathrm{t}-1+0.2347 \mathrm{X} \mathrm{t}-0.03906 \mathrm{X} \mathrm{t}+1$

2nd quarter $=0.00781 \mathrm{Xt}-1+0.26563 \mathrm{X} \mathrm{t}-0.02344 \mathrm{X} \mathrm{t}+1$

3 rd quarter $=-0.02344 \mathrm{X} \mathrm{t}-1+0.26563 \mathrm{Xt}+0.00871 \mathrm{Xt}+1$

4 th quarter $=-0.03906 \mathrm{X} \mathrm{t}-1+0.23437 \mathrm{Xt}+0.05469 \mathrm{X} \mathrm{t}+1$

\section{Appendix No. (3)}

\section{Dependent Variable: LNGDP}

Method: ARDL

Date: 08/20/20 Time: $21: 38$

Sample (adjusted): 2002Q1 2014Q4

Included observations: 52 after adjustments

Maximum dependent lags: 4 (Automatic selection)

Model selection method: Akaike info criterion (AIC)

Dynamic regressors (4 lags, automatic): LNI LNX LNR DUMMY

Fixed regressors: $\mathrm{C}$

Number of models evalulated: 2500

Selected Model: ARDL $(1,4,2,4,4)$

Prob.* t-Statistic $\quad$ Std. Error Coefficient Variable 


\begin{tabular}{lllll}
\hline \hline 0.0000 & 15.90009 & 0.045988 & 0.731218 & LNGDP(-1) \\
0.0042 & -3.081999 & 0.031189 & -0.096124 & LNI \\
0.1545 & 1.458342 & 0.046307 & 0.067531 & LNI(-1) \\
0.4788 & 0.716553 & 0.044499 & 0.031886 & LNI(-2) \\
0.7031 & 0.384519 & 0.042936 & 0.016510 & LNI(-3) \\
0.1592 & 1.441283 & 0.039654 & 0.057153 & LNI(-4) \\
0.0000 & 9.080056 & 0.044125 & 0.400658 & LNX \\
0.0010 & -3.616531 & 0.075818 & -0.274199 & LNX(-1) \\
0.2655 & 1.133380 & 0.053856 & 0.061039 & LNX(-2) \\
0.0000 & 5.758264 & 0.028094 & 0.161773 & LNR \\
0.0028 & -3.240024 & 0.041008 & -0.132866 & LNR(-1) \\
0.9878 & -0.015424 & 0.039970 & -0.000616 & LNR(-2) \\
0.9823 & -0.022342 & 0.039530 & -0.000883 & LNR(-3) \\
0.0928 & -1.732516 & 0.046130 & -0.079920 & LNR(-4) \\
0.4958 & -0.689030 & 0.019634 & -0.013528 & DUMMY \\
0.0199 & 2.451025 & 0.014784 & 0.036236 & DUMMY(-1) \\
0.1980 & 1.314522 & 0.014752 & 0.019392 & DUMMY(-2) \\
0.8624 & 0.174745 & 0.014502 & 0.002534 & DUMMY(-3) \\
0.0693 & 1.879752 & 0.012191 & 0.022916 & DUMMY(-4) \\
0.0480 & -2.055913 & 0.375618 & -0.772238 & C \\
\hline \hline 13.94904 & \multicolumn{2}{|c}{ Mean dependent var } & 0.999723 & R-squared \\
0.472765 & S.D. dependent var & 0.999559 & Adjusted R-squared \\
-6.102120 & Akaike info criterion & 0.009933 & S.E. of regression \\
-5.351642 & Schwarz criterion & 0.003157 & Sum squared resid \\
-5.814405 & Hannan-Quinn criter. & 178.6551 & Log likelihood \\
1.916359 & Durbin-Watson stat & 6078.523 & F-statistic \\
& & & 0.000000 & Prob(F-statistic) \\
\hline \hline
\end{tabular}

*Note: p-values and any subsequent tests do not account for model selection

Appendix No. (4)

ARDL Cointegrating And Long Run Form

Original dep. variable: LNGDP

Selected Model: ARDL $(1,4,2,4,4)$

Date: 08/23/20 Time: 15:08

Sample: 2001Q1 2014Q4

Included observations: 52

Cointegrating Form

\begin{tabular}{lllll}
\hline \hline Prob. & t-Statistic & Std. Error & Coefficient Variable \\
\hline \hline 0.0006 & -3.802434 & 0.025280 & -0.096124 & $\mathrm{D}(\mathrm{LNI})$ \\
0.0007 & -3.756924 & 0.028094 & -0.105548 & $\mathrm{D}(\mathrm{LNI}(-1))$ \\
0.0113 & -2.687526 & 0.027409 & -0.073663 & $\mathrm{D}(\mathrm{LNI}(-2))$
\end{tabular}




$\begin{array}{lllll}0.0509 & -2.028644 & 0.028173 & -0.057153 & \mathrm{D}(\mathrm{LNI}(-3)) \\ 0.0000 & 11.442884 & 0.035014 & 0.400658 & \mathrm{D}(\mathrm{LNX}) \\ 0.1539 & -1.460603 & 0.041790 & -0.061039 & \mathrm{D}(\mathrm{LNX}(-1)) \\ 0.0000 & 7.772428 & 0.020814 & 0.161773 & \mathrm{D}(\mathrm{LNR}) \\ 0.0020 & 3.357527 & 0.024250 & 0.081420 & \mathrm{D}(\mathrm{LNR}(-1)) \\ 0.0013 & 3.526693 & 0.022912 & 0.080803 & \mathrm{D}(\mathrm{LNR}(-2)) \\ 0.0017 & 3.428962 & 0.023307 & 0.079920 & \mathrm{D}(\mathrm{LNR}(-3)) \\ 0.1815 & -1.365845 & 0.009905 & -0.013528 & \mathrm{D}(\mathrm{DUMMY}) \\ 0.0001 & -4.378135 & 0.010242 & -0.044842 & \mathrm{D}(\mathrm{DUMMY}(-1)) \\ 0.0159 & -2.545311 & 0.009999 & -0.025450 & \mathrm{D}(\mathrm{DUMMY}(-2)) \\ 0.0266 & -2.323847 & 0.009861 & -0.022916 & \mathrm{D}(\mathrm{DUMMY}(-3)) \\ 0.0000 & -13.738011 & 0.019565 & -0.268782 & \text { CointEq(-1) }\end{array}$

CointEq $=$ LNGDP $-(0.2863 * \mathrm{LNI}+0.6976 * \mathrm{LNX}-0.1954 * \mathrm{LNR}+0.2513$

*DUMMY -2.8731 )

Long Run Coefficients

\begin{tabular}{lllll}
\hline \hline Prob. & t-Statistic & Std. Error & Coefficient Variable \\
\hline \hline 0.0010 & 3.611062 & 0.079287 & 0.286312 & LNI \\
0.0000 & 5.317528 & 0.131185 & 0.697582 & LNX \\
0.0889 & -1.754722 & 0.111341 & -0.195372 & LNR \\
0.0000 & 5.306693 & 0.047359 & 0.251320 & DUMMY \\
0.0789 & -1.815215 & 1.582788 & -2.873099 & C \\
\hline \hline
\end{tabular}

\section{Appendix No. (5)}

skedasticity Test: Breusch-Pagan-Godfrey

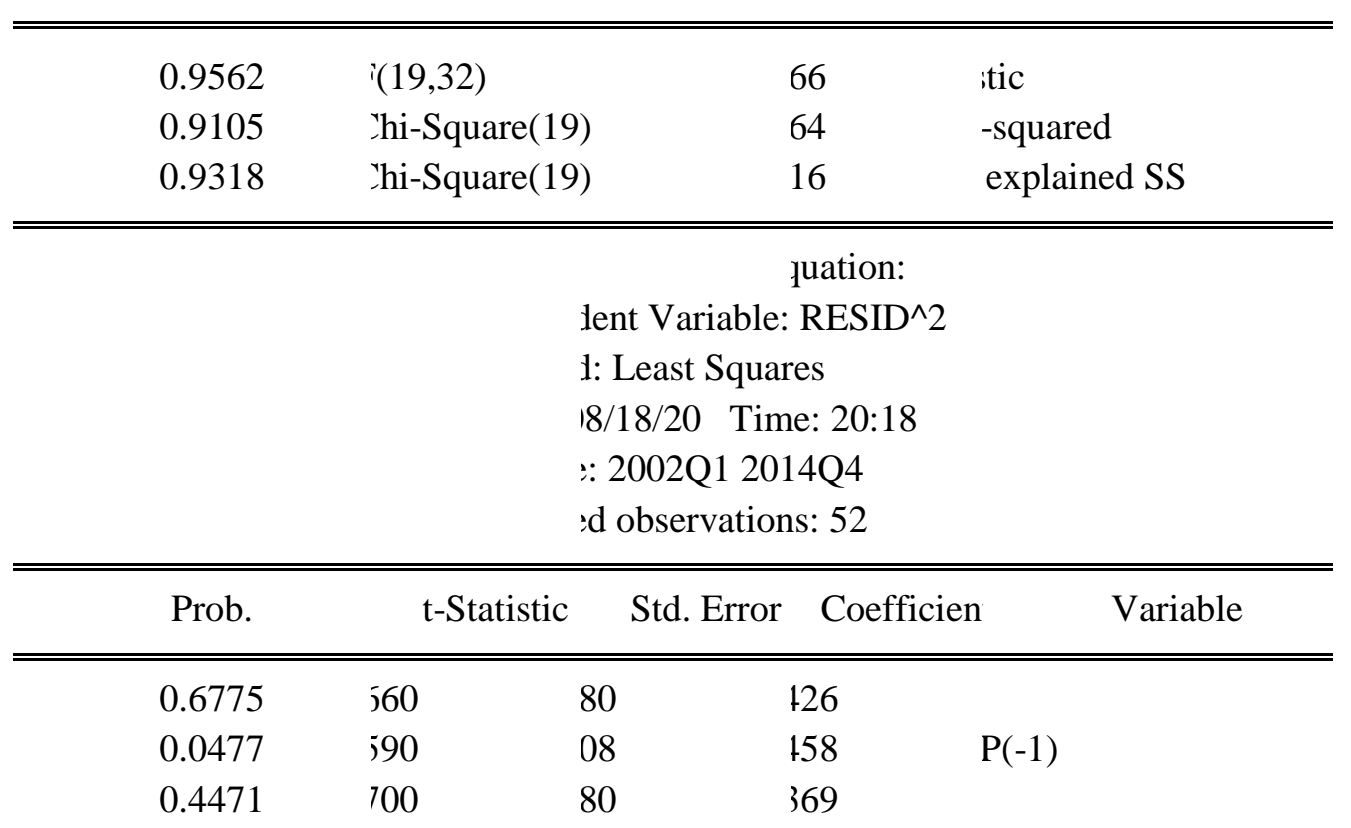




\begin{tabular}{|c|c|c|c|c|}
\hline 0.5768 & 68 & 13 & 02 & ) \\
\hline 0.7043 & 387 & 85 & 262 & ) \\
\hline 0.8658 & 366 & 61 & $\lfloor 13$ & ) \\
\hline 0.2266 & 48 & 10 & 52 & ) \\
\hline 0.5795 & 59 & 79 & 80 & \\
\hline 0.9498 & 26 & 67 & 35 & 1) \\
\hline 0.5580 & 27 & 29 & 91 & 2) \\
\hline 0.8515 & 787 & 32 & -05 & \\
\hline 0.6864 & 15 & 31 & 57 & 1) \\
\hline 0.9533 & 50 & 15 & -05 & 2) \\
\hline 0.6892 & 48 & 08 & 45 & 3) \\
\hline 0.1875 & 588 & 10 & 156 & 7) \\
\hline 0.2864 & 24 & 02 & 28 & $1 \mathrm{Y}$ \\
\hline 0.8928 & 50 & 28 & 35 & $1 Y(-1)$ \\
\hline 0.9299 & 15 & 27 & 35 & $1 Y(-2)$ \\
\hline 0.8391 & 64 & 23 & 35 & $1 Y(-3)$ \\
\hline 0.6644 & 85 & 88 & 35 & $1 Y(-4)$ \\
\hline $6.07 \mathrm{E}-05$ & \multicolumn{2}{|c|}{ lependent var } & 82 & red \\
\hline 0.000137 & \multicolumn{2}{|c|}{ spendent var } & 667 & ed R-squared \\
\hline-14.45036 & \multicolumn{2}{|c|}{ info criterion } & 53 & regression \\
\hline-13.69988 & \multicolumn{2}{|c|}{$\mathrm{z}$ criterion } & 37 & juared resid \\
\hline-14.16264 & \multicolumn{2}{|c|}{ ^-Quinn criter. } & 93 & elihood \\
\hline \multirow[t]{2}{*}{2.162286} & \multirow{2}{*}{\multicolumn{2}{|c|}{-Watson stat }} & 66 & ;tic \\
\hline & & & 09 & -statistic) \\
\hline
\end{tabular}

Appendix No. (6)

Breusch-Godfrey Serial Correlation LM Test:

\begin{tabular}{llll}
\hline \hline 0.9721 & Prob. F(2,30) & 0.028354 & F-statistic \\
0.9521 & Prob. Chi-Square(2) & 0.098110 & Obs*R-squared \\
\hline \hline
\end{tabular}

Test Equation:

Dependent Variable: RESID

Method: ARDL

Date: 08/23/20 Time: 15:07

Sample: 2002Q1 2014Q4

Included observations: 52

Presample missing value lagged residuals set to zero.

\begin{tabular}{lllll}
\hline \hline Prob. & t-Statistic & Std. Error & Coefficient & Variable \\
\hline \hline 0.9582 & 0.052903 & 0.049837 & 0.002637 & LNGDP(-1) \\
0.9837 & -0.020629 & 0.032461 & -0.000670 & LNI
\end{tabular}




\begin{tabular}{lllll}
0.9889 & 0.013986 & 0.047864 & 0.000669 & LNI(-1) \\
0.9991 & 0.001181 & 0.045987 & $5.43 \mathrm{E}-05$ & LNI(-2) \\
0.9925 & 0.009469 & 0.044462 & 0.000421 & LNI(-3) \\
0.9618 & -0.048320 & 0.043403 & -0.002097 & LNI(-4) \\
0.9817 & 0.023133 & 0.047404 & 0.001097 & LNX \\
0.9779 & -0.027972 & 0.080071 & -0.002240 & LNX(-1) \\
0.9885 & 0.014476 & 0.055840 & 0.000808 & LNX(-2) \\
0.9659 & 0.043089 & 0.029983 & 0.001292 & LNR \\
0.9671 & -0.041575 & 0.042979 & -0.001787 & LNR(-1) \\
0.9998 & 0.000254 & 0.042242 & $1.08 \mathrm{E}-05$ & LNR(-2) \\
0.9921 & -0.009938 & 0.040824 & -0.000406 & LNR(-3) \\
0.9659 & 0.043090 & 0.049601 & 0.002137 & LNR(-4) \\
0.9710 & -0.036677 & 0.020783 & -0.000762 & DUMMY \\
0.9918 & -0.010326 & 0.015271 & -0.000158 & DUMMY(-1) \\
0.9940 & -0.007621 & 0.015286 & -0.000116 & DUMMY(-2) \\
0.9966 & -0.004357 & 0.014967 & $-6.52 \mathrm{E}-05$ & DUMMY(-3) \\
0.9953 & -0.005989 & 0.012583 & $-7.54 \mathrm{E}-05$ & DUMMY(-4) \\
0.9773 & -0.028745 & 0.402199 & -0.011561 & C \\
0.8182 & -0.231931 & 0.201326 & -0.046694 & RESID(-1) \\
0.9997 & -0.000327 & 0.219811 & $-7.20 \mathrm{E}-05$ & RESID(-2) \\
\hline \hline$-5.86 \mathrm{E}-15$ & \multicolumn{5}{c}{ Mean dependent var } & 0.001887 & R-squared \\
0.007868 & \multicolumn{5}{c}{ S.D. dependent var } & -0.696793 & Adjusted R-squared \\
-6.027086 & Akaike info criterion & 0.010249 & S.E. of regression \\
-5.201560 & \multicolumn{5}{c}{ Schwarz criterion } & 0.003152 & Sum squared resid \\
-5.710599 & Hannan-Quinn criter. & 178.7042 & Log likelihood \\
1.843421 & Durbin-Watson stat & 0.002700 & F-statistic \\
& & 1.000000 & Prob(F-statistic) \\
\hline \hline
\end{tabular}

\section{Appendix No. (7)}

ARDL Bounds Test

Date: 08/22/20 Time: 17:06

Sample: 2002Q1 2014Q4

Included observations: 52

Null Hypothesis: No long-run relationships exist

\begin{tabular}{llll}
\hline \hline & $\mathrm{k}$ & Value & Test Statistic \\
\hline \hline & 4 & 27.20475 & F-statistic \\
\hline \hline
\end{tabular}

Critical Value Bounds

\begin{tabular}{l}
\hline \hline I1 Bound $\quad$ I0 Bound Significance \\
\hline \hline
\end{tabular}




\begin{tabular}{lll}
3.09 & 2.2 & $10 \%$ \\
3.49 & 2.56 & $5 \%$ \\
3.87 & 2.88 & $2.5 \%$ \\
4.37 & 3.29 & $1 \%$ \\
\hline
\end{tabular}

\begin{tabular}{|c|c|c|c|c|}
\hline \multirow[b]{2}{*}{ Prob. } & & \multicolumn{3}{|c|}{$\begin{array}{l}\text { Test Equation: } \\
\text { Dependent Variable: D(LNGDP) } \\
\text { Method: Least Squares } \\
\text { Date: 08/22/20 Time: 17:06 } \\
\text { Sample: 2002Q1 2014Q4 } \\
\text { Included observations: } 52\end{array}$} \\
\hline & t-Statistic & Std. Error & Coefficient & Variable \\
\hline 0.0042 & -3.081999 & 0.031189 & -0.096124 & $\mathrm{D}(\mathrm{LNI})$ \\
\hline 0.0093 & -2.766927 & 0.038146 & -0.105548 & $\mathrm{D}(\mathrm{LNI}(-1))$ \\
\hline 0.0538 & -2.001969 & 0.036795 & -0.073663 & $\mathrm{D}(\mathrm{LNI}(-2))$ \\
\hline 0.1592 & -1.441283 & 0.039654 & -0.057153 & $\mathrm{D}(\mathrm{LNI}(-3))$ \\
\hline 0.0000 & 9.080056 & 0.044125 & 0.400658 & $\mathrm{D}(\mathrm{LNX})$ \\
\hline 0.2655 & -1.133380 & 0.053856 & -0.061039 & $\mathrm{D}(\operatorname{LNX}(-1))$ \\
\hline 0.0000 & 5.758264 & 0.028094 & 0.161773 & $\mathrm{D}(\mathrm{LNR})$ \\
\hline 0.0349 & 2.203464 & 0.036951 & 0.081420 & $\mathrm{D}(\operatorname{LNR}(-1))$ \\
\hline 0.0397 & 2.144709 & 0.037676 & 0.080803 & $\mathrm{D}(\operatorname{LNR}(-2))$ \\
\hline 0.0928 & 1.732516 & 0.046130 & 0.079920 & $\mathrm{D}(\operatorname{LNR}(-3))$ \\
\hline 0.4958 & -0.689030 & 0.019634 & -0.013528 & D(DUMMY) \\
\hline 0.0014 & -3.495282 & 0.012829 & -0.044842 & D(DUMMY(-1)) \\
\hline 0.0475 & -2.061500 & 0.012345 & -0.025450 & D(DUMMY(-2)) \\
\hline 0.0693 & -1.879752 & 0.012191 & -0.022916 & D(DUMMY(-3)) \\
\hline 0.0480 & -2.055913 & 0.375618 & -0.772238 & $\mathrm{C}$ \\
\hline 0.0150 & 2.571303 & 0.029929 & 0.076956 & LNI(-1) \\
\hline 0.0000 & 5.531147 & 0.033898 & 0.187498 & LNX(-1) \\
\hline 0.1212 & -1.592035 & 0.032984 & -0.052512 & LNR(-1) \\
\hline 0.0033 & 3.174412 & 0.021280 & 0.067550 & DUMMY(-1) \\
\hline 0.0000 & -5.844577 & 0.045988 & -0.268782 & LNGDP(-1) \\
\hline 0.025962 & \multicolumn{2}{|c|}{ Mean dependent var } & 0.941585 & $\begin{array}{l}\text { R-squared } \\
\text { Adjusted }\end{array}$ \\
\hline 0.032555 & \multirow{3}{*}{\multicolumn{2}{|c|}{$\begin{array}{l}\text { S.D. dependent var } \\
\text { Akaike info criterion }\end{array}$}} & 0.906900 & squared \\
\hline-6.102120 & & & 0.009933 & S.E. of regression \\
\hline & & & & Sum squared \\
\hline-5.351642 & \multirow{4}{*}{\multicolumn{2}{|c|}{$\begin{array}{l}\text { Schwarz criterion } \\
\text { Hannan-Quinn criter. } \\
\text { Durbin-Watson stat }\end{array}$}} & 0.003157 & resid \\
\hline-5.814405 & & & 178.6551 & Log likelihood \\
\hline 1.916359 & & & 27.14737 & F-statistic \\
\hline & & & 0.000000 & Prob(F-statistic) \\
\hline
\end{tabular}

